\title{
MADREPORA PILEUS.
}

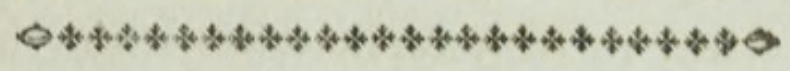

CHARACTER GENERICUS.

Animal Medusa.

Corallium cavitatibus lamelloso-stellatis.

Lin. Syst. Nat.

CHARACTER SPECIFICUS, छొC.

MADREPORA ovato-elongata albida, sulco longitudinali medio.

MADREPORA PILEUS. M. simplex acaulis oblonga, stella convexa conglomerato-lamellosa, lamellis abbreviatis, subtus concava.

Lyn. Syst. Nat. p. 1273.

Mitra Neptuni.

- Tournef. act. Paris. 1700. p. 30.

Pileus Neptuni.

Seb. mus. 3. t. 111. f. 3. 5.

In oceano Indico reperta, quam descripsimus, Madrepora, major sxpe est icone quæ ostenditur in tabula, Color albo-flavescit. 


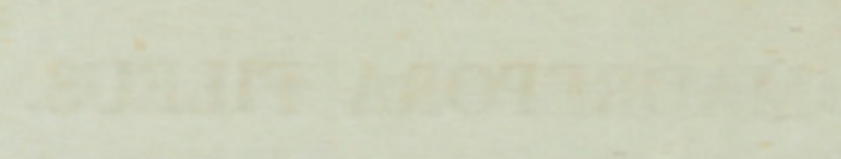




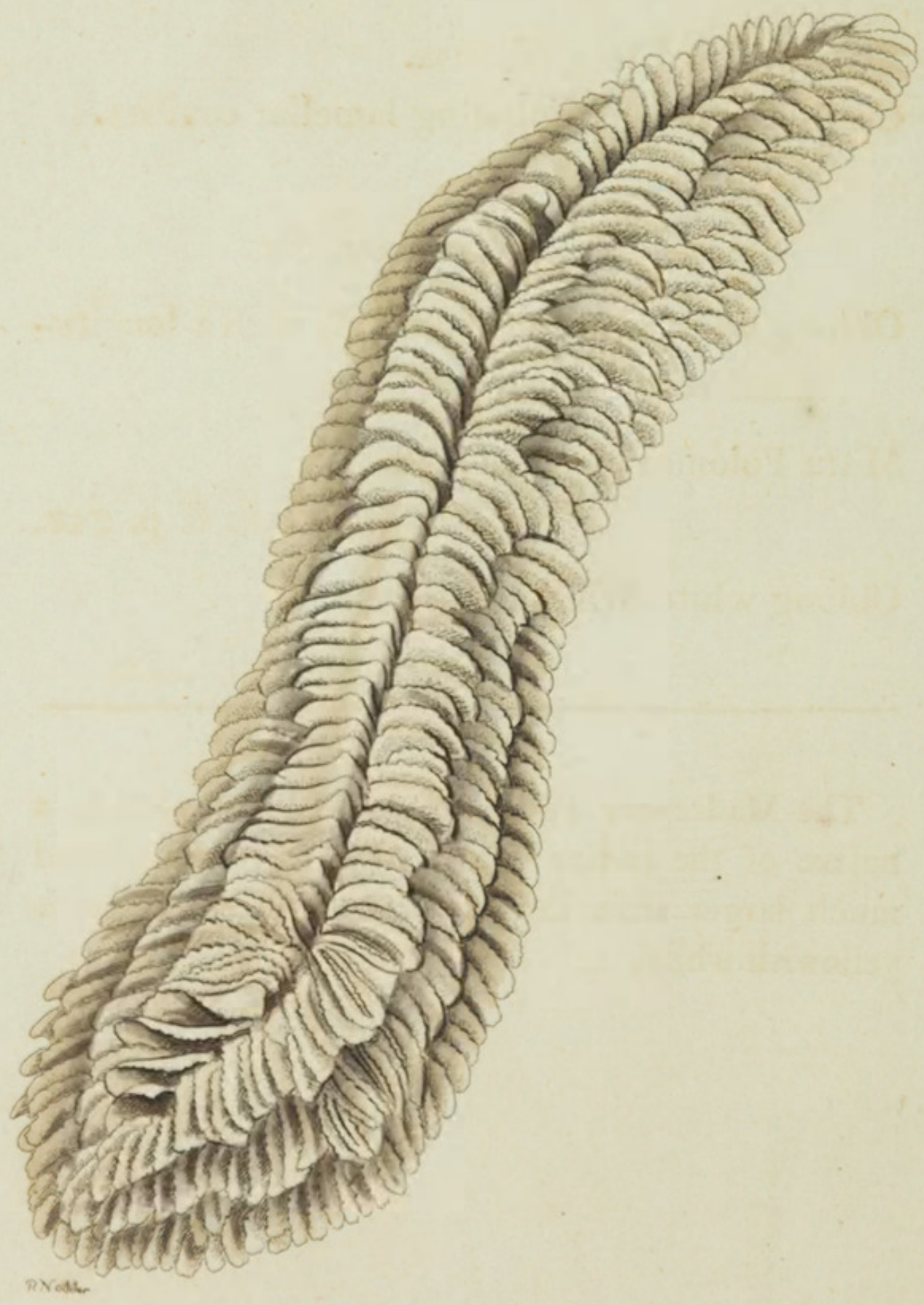




\section{OBLONG MADREPORE.}

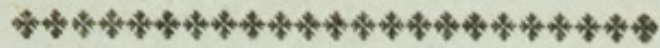

GENERIC CHARACTER。

Animal allied to a Medusa.

Coral marked by radiating lamellar cavities.

\section{$S_{\text {PECIFIC }} C_{\text {HARACTER }}$ E $\boldsymbol{C}$.}

Oblong whitish MADREPORE, with a longitudinal central furrow.

Mitra Polonica.

Rumph. Amb. 6. p. 248.

Oblong white MADREPORE.

The Madrepore figured on the present plate is a native of the Indian seas, and is frequently found much larger than here represented: its colour is yellowish white. 


\section{$2 \mathrm{BHL}$ Biodiversity Heritage Library}

Shaw, George. 1804. "Oblong Madrepore, Madrepora pileus [PI. 623]." The Naturalist's Miscellany 15(CLXXVIII), https://doi.org/10.5962/p.311064.

View This Item Online: https://www.biodiversitylibrary.org/item/280634

DOI: https://doi.org/10.5962/p.311064

Permalink: https://www.biodiversitylibrary.org/partpdf/311064

\section{Holding Institution}

Museums Victoria

\section{Sponsored by}

Atlas of Living Australia

\section{Copyright \& Reuse}

Copyright Status: Public domain. The BHL considers that this work is no longer under copyright protection.

This document was created from content at the Biodiversity Heritage Library, the world's largest open access digital library for biodiversity literature and archives. Visit BHL at https://www.biodiversitylibrary.org. 